\title{
THE EFFECT OF ROLE PLAYING STRATEGY ASSISTED BY PAPER PUPPETS AS MEDIA TO THE STUDENTS' SPEAKING COMPETENCY
}

\author{
Yani, P.I. ${ }^{1}$, Jampel, I.N. ${ }^{2}$, Jayanta, I.N. ${ }^{3}$ \\ 1,2,3 Ganesha University of Education, Singaraja, Indonesia
}

\begin{tabular}{l} 
A R T I C L E I N F O \\
\hline Article history: \\
Received 12 March 2018 \\
Received in revised form \\
09 April \\
Accepted 14 May 2018 \\
Available online 25 June \\
2018 \\
\hline Keywords: \\
Role-Play, \\
Puppet Show Media, \\
Speaking Skill
\end{tabular}

\section{A R T I C L E I N F O} 09 April

Accepted 14 May 2018

Available online 25 June

Keywords

Puppet Show Media,

Speaking Skil

\begin{abstract}
A B S T R A C T
The purpose of this study is to determine the speaking skill differences regarding to Bahasa as the subject between students who were taught by using puppet show as media of role-play supporting model and students who were not taught by using puppet show at second semester of fifth grade elementary school on Cluster III of Banjar District, Buleleng Regency in academic year 2017/2018. The population of this research is the 114 fifth grade students on Cluster III Banjar District, Buleleng Regency in academic year 2017/2018 as well. Meanwhile, the samples of the research are 17 fifth grade students from SD Negeri 2 Dencarik and 15 fifth grade students from SD Negeri 3 Dencarik. Assessment of speech is used as the instrument of data collection. Then, the collected data is analyzed by using descriptive and inferential statistical analysis ( $t$-test). Tcal $=6,93>t t a b=1,69$ is obtained based on the results of analysis which means that there is significant difference between students who were taught by using puppet show as media of role-play supporting model and students who were not taught by using puppet show for Bahasa as learning subject for second semester of fifth grade elementary school on Cluster III of Banjar District, Buleleng Regency in academic year 2017/2018. This researcher suggests that it can be used as a guide in further research about puppest show as media of role-play supporting model in Bahasa or any other subject as field of study.
\end{abstract}

\section{Introduction}

Learning in elementary school is a process of interaction between various potentials of students (Physical, non-physical, emotional, and intellectual), interaction between students with teachers, students with other students, and the environment with concepts and facts, interaction of various stimuli with various directed responses to childbirth change (Susanto, 2013). In the process of learning in elementary schools there are various problems, such as the low quality of learning seen from the way teachers do not encourage students to develop students' thinking skills by interacting with other students, as well as by the way students talk with friends, and everyone in their environment. Therefore the teacher can apply or choose a learning strategy to improve students' speaking skills. In designing learning a teacher must pay attention to the objectives of the learning itself, include the learning of Indonesian. Indonesian language learning is one of the best language skills in elementary school and is the most important capital for humans. In teaching Indonesian language, there are four language skills that must be possessed by students, these skills include listening, speaking, reading and writing, these four aspects of language are interrelated between one another (Susanto 2013).Speaking is one aspect of language to convey the intentions (ideas, thoughts, and hearts) of someone to others by conveying them using spoken language so that the purpose can be accepted and understood by others well. Related to the statement, the quality of education at the elementary level, the ability to speak in communication is still a problem or problem experienced by students. Based on the observations done on Wednesday 29 November 2017 that students' speaking skills in SDN Gugus III, Banjar District, Buleleng Regency could not be said to be good, this could be seen from the observations in each school in Gugus III that students were less able to recite 
properly, the way to speak still stammered, in conveying the dialogue students lack of inspiration so that they could not convey the feelings of the characters in the story, students were also less confident in front of the class so that the mastery in front of class was still lacking and students were also less able to express opinions in front of the class. The statement of the observation results was also strengthened by the results of the interviews with head master and Indonesian teachers in Gugus III of Banjar District, Buleleng Regency, which found that classroom learning, especially Indonesian language learning, generally applied teacher center, question and answer, and assignment, even the teacher have used model in Indonesian language learning but the model used by the teacher is still ineffective to arouse students 'interest in improving students' speaking skills. However, a teacher must do variations in learning activities by applying innovative learning models so that students obtain optimal learning outcomes. One innovative learning model that can be used in Indonesian language learning, especially speaking skills is the role playing learning model.

According to Djamarah and Zain (in Wardana, 2014) Models of Role Playing and sociodrama can be said to be the same meaning, the Role Playing Model basically dramatizes behavior in the relation with social problems, while sociodrama is a method of teaching where students get the task of dramatizing social situations. So that the function was often replaced. The expected goal in the use of the Role Playing model is; (1) Making students can appreciate the feelings of others; (2) Can learn how to share responsibility; (3) Can learn how to make decisions in group situations spontaneously; (4) Stimulate classes to think and solve problems in class.

Passive learning will affect students' speaking skills. Therefore, besides applying the Role Playing learning model, researchers also use show puppet media in the Indonesian language learning process. Puppet media is a media that belongs to the type of visual media in the form of three dimensions, because this media can be seen and held. In Indonesian language learning, the material identifies the elements of the story demonstrated by puppet media in accordance with the story. So in this case, students are required to play characters in the story. The advantage of this media wayang is to clarify messages and information. So that, it is easily understood by students. Puppet media is indirectly able to encourage learning that involves students actively and will have an impact on optimal learning outcomes, especially in speaking skills in Indonesian language learning (Widayati 2017).

Based on the description, a research was conducted on Role Playing learning models assisted by wayang show in Indonesian learning with the title "The Influence of Role Playing Learning Models Assisted by Puppet Media Show on Indonesian Speaking Skills of Students in Class V Semester II SDN in Group III Banjar District, Buleleng Regency 2017/2018 Academic Year ".

\section{Methods}

This research is an experimental research, considering that the control or the control of variables cannot be done strictly, or in full, it is called quasi experimental research. The design of this study used a "non-equivalent post-test only with equivalent control group design" experimental design.

Table 1. The results of the t-test analysis of science knowledge competencies (Gall in Agung, 2014)

\begin{tabular}{ccc}
\hline Group & Treatment & Post-test \\
\hline Exsperiment & $\mathrm{X}$ & $\mathrm{O}_{1}$ \\
Control & - & $\mathrm{O}_{2}$ \\
\hline
\end{tabular}

Note:

E: Experiment Class

K: Control Class

$\mathrm{X}$ : Treatment, namely learning with Role Playing assisted by paper puppets

-: Without being given treatment

01: Post-test experimental class

02: Post-test control class

The first group consisting of one class was an experimental class which was taught by a Role Playing model assisted by puppets show, while the second group which also consisted of one class was a control class that was not taught by the Role Playing learning model assisted by puppets show in Indonesian subjects by class V students of SDN in Gugus III Banjar District, Buleleng Regency 2017/2018 Academic Year.

Research Population in the study were all groups of V class students of SDN in Gugus III of Banjar District, Buleleng Regency, with total seven classes consisting of 114 students and divided into seven 
elementary schools, namely SDN 4 Banjar, SDN 1 Banjar Tegehe, SDN 3 Banjar Tegehe, SDN 1 Tampekan, SDN 3 Dencarik, SDN 2 Dencarik, SDN 1 Dencarik. The composition of the number of students each elementary school is presented in table 2 below.

Table 2. Composition of Population Members

\begin{tabular}{clccc}
\hline NO & Population class & Class & Students Frequency \\
\hline 1 & SD N 4 Banjar & & $\mathrm{V}$ & 14 \\
2 & SD N 1 Banjar Tegehe & & $\mathrm{V}$ & 13 \\
3 & SD N 3 Banjar Tegehe & & $\mathrm{V}$ & 14 \\
4 & SD N 1 Tampekan & & $\mathrm{V}$ & 17 \\
5 & SD N 3 Dencarik & & $\mathrm{V}$ & 15 \\
6 & SD N 2 Dencarik & & $\mathrm{V}$ & 17 \\
7 & SD N 1 Dencarik & Total & & 24 \\
\hline
\end{tabular}

So the population in this study were 7 schools in Gugus III Banjar District, Buleleng Regency with the total number of students 114 people with the distribution of the number of students in each school can be seen in table 2.2 above.

In this study the sample selection technique used to select the experimental class and the control class is by random sampling. This technique is used as a sampling technique because individuals in the population have been distributed into classes so that it is not possible to randomize individuals in the population.

The first phase of the seven schools in Gugus III in Banjar District, Buleleng Regency, was drawn to draw two groups that were used as research samples. The two groups were drawn again to determine the experimental group that was taught by the Role Playing learning model assisted by the Puppet Show Media and one group as a control group that was not taught by the Role Playing learning model assisted by the Puppet Show Media or the learning took place as usual by the teacher. Based on the drawn results to determine the experimental and control groups, it was obtained that the V class of SD Negeri 3 Dencarik as an experimental group that was learned by the Role Playing learning model assisted by Puppet Show Media, while the control group was obtained in class V SD Negeri 2 Dencarik which was not taught with assisted Role Playing models Puppet Show Media.

This study involve two variable, namely role playing learning model assisted by the Puppet Media Show as a independent variable, and speaking skill of Indonesian language as dependent variable. In the experiment group were taught by role playing learning model assisted by the Puppet Media Show, while in the control group were not taught by role playing learning model assisted by the Puppet Media Show. The learning process were taught 7 meeting and 1 meeting for post-test. Speaking skill of Indonesian language measured by post-test.

In this study, in examining speaking skill, an assessment rubric was used with a rating scale. The research rubric with a rating scale could be used to measure speaking skill, the instrument validity tasted by using logical validity. According to Basrowi dan Siskandar (2012), the term logic validity contained with "logic" words come from the word logic which means reasoning. So, the logical validity for an evaluation instrument refers to the conditions for instrument that complete the valid requirements based on the results of reasoning. Valid conditions are considered fulfilled because the instrument in the question has been designed well to follow existing theories and provisions. The instrument was designed with the condition of an instrument that complete valid requirements based on the results of reasoning. So that, logic validity did not need to be tasted for its condition but immediately obtained after the instrument complete.

The data needed in this research is Indonesian speaking skills. The form of observation rubric is Indonesian speaking skill. Data analysis method used in this research is descriptive statistical analysis method and inferential statistics (t-test). Descriptive analysis is used o find out the description of Indonesian speaking skill by looking for mean, median, modes, standard deviations, ranges and variants. Next, the inferential statistics used to hypothesis test. Before testing the hypothesis several precondition test were carried out in the form of normality test and homogeneity test, while the data analysis method used for test the hypothesis is t-test analysis.

\section{Findings and Discussion}

The results of the descriptive analysis of the data of Indonesian speaking skills in the experimental group showed that the average score was 88.13 with high category and the measurement of Indonesian speaking skills in the control group showed that the average score was 77.82 with high category. The 
summary of the results of the data description of Indonesian speaking skills in this study can be seen in Table 3.

Table 3. Summary of Data on Indonesian Speaking Skills

\begin{tabular}{ccc}
\hline \multirow{2}{*}{ Descriptive Statistics } & \multicolumn{2}{c}{ Indonesian Speaking Skill } \\
\cline { 2 - 3 } & Experimental Group & Control Group \\
\hline Mean & 88,13 & 77,82 \\
Median & 90,13 & 77 \\
Modes & 90,22 & 67,3 \\
Variants & 45,98 & 65,15 \\
Standard Deviation & 6,78 & 8,07 \\
Maximum Score & 100 & 70 \\
Minimum Score & 90 & 60 \\
Average & 30 & 30
\end{tabular}

Based on the results of the descriptive analysis in Table 3.1, the average score of Indonesian speaking skills in the experimental group was greater than the average score of the control group of Indonesian speaking skills. This review is based on the average score and tendency of students' speaking skills scores obtained by both groups. In the experimental group, the average score of Indonesian speaking skills in the control group was 88.13 in the high category and the majority of students' scores tended to be above the average. Data description of Indonesian speaking skills in the control group can be presented in Figure 1.

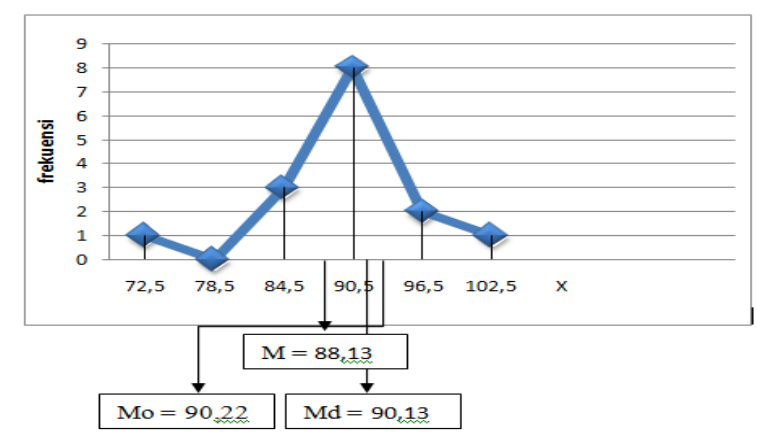

Figure 1. Polygon Curve Data speaking skills of Experimental Group

In the control group, the average score of Indonesian speaking skills in the control group was 77.82 in the high category and the majority of students' scores tended to be low. The figure of data on Indonesian speaking skills in the control group can be presented in Figure 2.

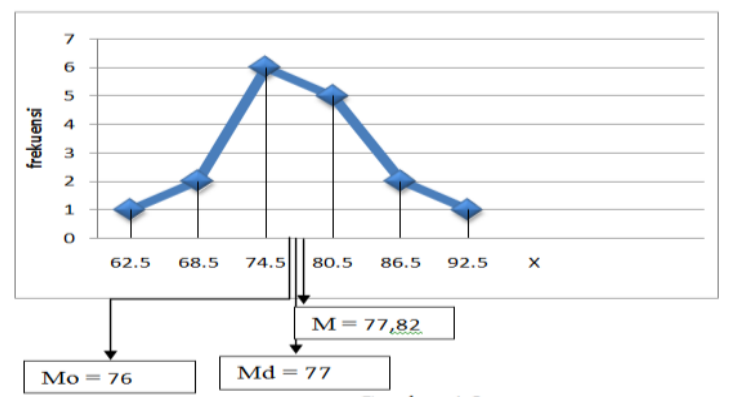

Figure 2. Polygon Curve Data on Indonesian speaking skills Control group

The results of this study indicate that experimental group speaking skills different from control group speaking skills. The students' speaking skills in the experimental group different from the speaking skills in the control group, in which the experimental group was applied the role playing learning model assisted by Puppet Media Show. Yuliani (2017) states that Role playing is a kind of motion game in which there are goals, rules and at the same time involves elements of pleasure. In role playing, students are conditioned in certain situations outside the classroom, even though at that time learning occurs in the 
classroom. Besides that, role playing is often intended as a form of activity in which students imagine themselves as if they are outside the classroom and play the role of people, role playing also functions as a grower of word characters or use of expressions. In addition, the role playing learning model is also a way of mastering learning materials through developing students' imagination and appreciation of the material provided. The development of imitation and appreciation is carried out by students by acting as a real figure or inanimate object, in the implementation of this model carried out by more than one person, all depends on what is played. The purpose of this learning model is to explain an event which involves many people, and based on consideration is better to be dramatized rather than told, because it will be clearer and can be internalized by the child, so that the child can explore and be interested in the story. In addition this model will train students, so that they are able to solve psychological social problems and can train students to get socialize and give possibilities for understanding other people along with their problems (Kurniasih and Sani, 2015: 68).

The advantages of role playing learning model according to Huda (2014: 210) include (1) can give the impression of a strong and durable learning in students' memories, (2) can be a fun learning experience that is difficult to forget, (3) make the classroom atmosphere more dynamic and enthusiastic, (4) arousing passion and a spirit of optimism in students and fostering a sense of togetherness, (5) making students jump directly to play something that will be discussed in the learning process. How to apply the role playing learning model is through developing students' imagination and appreciation of the material provided and it is a form of educational game that used to explain the roles, attitudes, and behavior of others. The development of imagination and appreciation is carried out by students by acting as a real figure and inanimate objects using puppet media show. Puppet is one of the cultural assets of the Indonesian nation that has been recognized worldwide but its existence in the country itself is increasingly in demand, especially by the younger generation. This was allegedly due to the lack of efforts to get to know of puppet in the children's environment. Puppet is a form of high quality cultural art manifestations that are in accordance with the nation's cultural values. Puppet is a form of traditional performance presented by a puppeteer, using puppets or by using materials in the surrounding environment such as paper and the other as a performance tool (Kamil, 2013).In addition, several regions such as Sumatra and the Semenanjung Malaya also have several Puppet cultures which are influenced by Javanese and Hindu culture. UNESCO as one of the UN agencies in charge of matters related to culture, on November 7, 2003, recognizing puppet as a show of shadow of famous dolls from Indonesia, a priceless masterpiece of the world in the art of narrative. Puppets consist of various types, according to the material in its origin. According to the type of material the puppet is made up of shadow puppets, wooden puppets, people puppets, grass puppets and puppets multicar. While according to the region of origin, consists of Surakarta puppets, East Javanese puppets, Balinese puppets, Sasak puppets (NTB), Shadow puppets Banjar (South Kalimantan) and many more types of puppets from their native regions. Although puppets is one of the performing arts that has been classified for a long time, but the audience is still there. Several times this show can be watched through television channels. But watching a puppet show in live is often more interesting than watching it on television. One possible reason is that when watching television, the audience can only see from one angle. Whereas if the audience see the performance directly, the audience can see from several angles as desired, as in Bali the puppets performance art is very often present in religious ceremonies in Bali (Pranatalisa, 2014).Because of that the paper puppet media is able to attract students' interest in learning. The results of the application of this model, students become more understanding about the content in a story that conveyed, students are able to appreciate the role played as well as students are able to learn social behaviors and values, besides that students' self confidence is better so that students are able to express their opinions in public with confident, while in the control group did not apply the role playing learning model assisted by puppets media but instead applied the teacher center method of discussion, question and answer and assignment. As a result students follow the learning well but students have not been able to understand the learning material properly.

These differences can also have a different impact on Indonesian speaking skills between learning using role playing learning models assisted by puppets media rather than did not use role playing learning models asissted by puppets media show. Thus, it can be concluded that the media-assisted role playing learning model with puppets show has a positive effect on Indonesian speaking skills of fifth grade students of SD Negeri 3 Dencarik Banjar District, Buleleng Regency 2017/2018 Academic Year.

The statement above is in line with the findings of the research by Widiantara (2013) which states that role playing learning models can improve Indonesian speaking skills, the impact is that students are more interested in learning, because they play their own role, it is easy to understand the social problems played. For students by acting like other people, they can put themselves in the character of others. Wimpiadi (2014) showed that the effect of implementing role playing learning models on Indonesian speaking skills, students are more eager to learn and practice speaking skills, so that the goals to be 
achieved in learning can run optimally. Wahyuningsih (2016) showed that efforts to improve the ability to speak through the puppets media show can improve speaking skills so that the teacher is able to do fun learning and students' speaking skills will increase and students are able to convey ideas with simple sentences.

In the explanation of the findings of the research above, it can be seen that the learning model of role playing assisted by puppets show is able to influence students' ability to speak Indonesian. The results of the findings above are strengthened by the results of the research that has been done, where in the experimental group which used the role playing learning model assisted by puppets show, it can improve students' speaking skills. In the research that had been implemented at SDN 3 Dencarik as an experimental group, where students were very enthusiastic to participate in learning, the activeness of students to show their speaking skills were increasingly visible, students were able to convey various problems faced in class with confidence and without stammering, in the use of Indonesian students has been better than before, students' speaking skills have increased. Besides that, learning speaking skills are also supported by puppets media which makes students more eager to learn because by using puppet media students desire to learn increasingly, and then students also began to know how to play puppets in front of the class, with puppet media students were also encouraged to be able to express, animate and express intentions with every movement they bring well, so that the atmosphere in the classroom becomes increasingly. The students' more pleasure and desire in following the learning especially the learning of Indonesian speaking skills was increasing.

The statement was also strengthened by the statement from the teacher's opinion that the influence of the role playing assisted learning model of puppet media is very good to be applied in elementary school, because through playing role learning students are able to express the feelings they feel without any doubt with an inspiration and self-confidence, Puppet paper media also greatly supports students to be active in learning so that the class becomes more enjoyable.

\section{Conclusion}

Based on the research problem and the results of the study, the conclusions in this study were, there were differences in Indonesian speaking skills between students who were taught with Role Playing learning models based on puppets media show with groups of students who were not taught using the Role Playing learning model with paper puppet media in Gugus III Banjar District Buleleng Regency 2017/2018 Academic Year. This is shown in the results of the $t$-test hypothesis which was known that $t$ count $=6.93>\mathrm{t}$ table $=1.69$ means that $\mathrm{H} 0$ was rejected and $\mathrm{H} 1$ was accepted. This means that there were differences in Indonesian speaking skills between students who were taught with Role Playing learning models based on puppets media with groups of students who were not taught using Role Playing learning models based on puppets media show in GUGUS III Banjar District, Buleleng Regency 2017/2018 Academic Year.

The suggestions that can be submitted based on the research that has been done as follows. (1) It is suggested to students to be more brave to raise problems and express their opinions in front of the class without any lack of confidence, especially in Indonesian subjects through the application of a role-playing learning model with puppets media as to improve students' speaking skills well. (2) It is recommended that elementary school teachers create more learning by applying innovative learning models, so that students become more enthusiastic about learning, one of the learning model is Role Playing and supported by relevant learning media to improve students' speaking skills, especially in Indonesian language subject. Because it has been proven in this study that there were significant differences in student speaking skills between students who were taught with Role Playing learning models based on puppets media with groups of students who were not taught using Role Playing learning models based on puppets media show. (3) It is recommended that head master should be able to take action in an effort to improve the quality of learning through directing teachers as an alternative choice using innovative learning models, one of them is the Role Playing learning model. (4) Researchers who are interested in conducting further research on Role Playing learning models in the field of Indonesian language and other appropriate fields of study in order to pay attention to the constraints experienced in this study as consideration for the improvement and refinement of research to be implemented.

\section{References}

\section{Basrowi., Siskandar. (2012). Evaluasi Belajar Berbasia Kinerja. Bandung: Karya Putra Darwati}

Darmawan, (2014). Pengaruh Model Pembelajaran Role Playing Terhadap Keterampilan Berbicara Bahasa Indonesia Siswa Kelas V. Singaraja, Volume 2, Nomor 1. 
Huda, M. (2014). Model-Model Pengajaran dan Pembelajaran Isu-isu Metodis dan Paradigmatis. Yogyakarta: Pustaka Pelajar.

Pranatalisa, (2014). Model Teknologi Untuk Media Promosi Visual Kesenian Wayang Kulit. Semarang, Volume 1, Nomor 1.

Kamil, dkk. (2013). Penggunaan M edia Permainan Kartu Kuartet Dalam Upaya Peningkatan Pemahaman Materi Wayang Kulit Purwa. Solo, Volume 1, Nomor 8.

Kurniasih, I., Sani. B. (2016). Ragam Pengembangan Model Pembelajaran Untuk Peningkatan Profesionalitas Guru. Singaraja: Kata Pena.

Susanto, Ahmad. (2013). Teori Belajar \& Pembelajaran di Sekolah Dasar. Jakarta: Kencana Prenadamedia Group.

Wahyuningsih. (2016). Upaya Meningkatkan Kemampuan Berbicara Melalui Permainan Wayang Kertas Pada Anak Usia 5-6 Tahun Di Paud Harapan Kelurahan Sukamulia Kecamatan Sail Kotamadya Pekanbaru. Pekanbaru, Volume 3, Nomor 1.

Widayanti, (2017). Penggunaan Media Wayang Untuk Meningkatkan Keterampilan Menyimak Cerita Pendek. Mojokerto, Volume 2, Nomor 1.

Widiantara, (2013). Pengaruh Metode Pembelajaran Role Playing Berbantuan Media Audio-Visual Terhadap Keterampilan Berbicara Pelajaran Bahasa Indonesia Siswa Kelas V Desa Penglatan. Singaraja, Volume 1, Nomor 1. 